Syntax Literate: Jurnal Ilmiah Indonesia p-ISSN: 2541-0849

e-ISSN: 2548-1398

Vol. 5, No. 11, November 2020

\title{
PELAYANAN KESEHATAN BERBASIS TI DALAM PROSES PEMENUHAN HAK-HAK TAHANAN DAN NARAPIDANA
}

\section{Puspitadini Cahyaning Utami dan Dedi Kurniawan}

Politeknik Ilmu Pemasyarakatan Depok Jawa Barat, Indonesia

Email: puspita3248@gmail.com dan dekur4951@gmail.com

\section{Abstract}

This study aims to find out and analyze health services in Cipinang Class 1 State Detention Center. By using a qualitative approach that is described descriptively and data collection is observed in the field. As for the background of this writing because the number of prisoners and detainees amounted to 221,763, while the number of medical personnel is only 1,062 people, so a comparison between the number of medical personnel and prisoners/prisoners namely 1: 185. This causes less than optimal health services for prisoners. Comprehensive health services promotive, preventive, curative, rehabilitative health services, midwifery services, and Emergency Medical Health Services, including supporting services that include simple laboratory examinations and pharmaceutical services by statutory provisions. In health service activities in Class Detention Centers 1, Cipinang always carries out preventive, healing, healing, and health promotion measures. The obstacles experienced by medical staff in conducting health services are due to the lack of infrastructure and the lack of medical personnel. The efforts made by medical personnel in optimizing their performance by always trying to complete the facilities and infrastructure. Based on the results of the analysis also, the authors suggest that the solution to overcome the loss of medical personnel is by running an online clinic (Telemedicine).

Keywords: Services; Telemedicine; Health

\section{Abstrak}

Penelitian ini bertujuan untuk mengetahui dan menganalisis pelayanan kesehatan yang ada di Rumah Tahanan Negara Kelas 1 Cipinang. Metode penelitian ini menggunakkan pendekatan kualitatif yang di jelaskan secara deskriptif dan pengambilan data secara observasi di lapangan. Adapun yang menjadi latar belakang penulisan ini karena jumlah narapidana dan tahanan berjumlah 221.763, sedangkan jumlah petugas medis hanya 1.062 orang, sehingga didapatkan perbandingan antara jumlah tenaga medis dengan narapidana/tahanan yaitu 1:185. Hal ini menyebabkan kurang optimalnya pelayanan kesehatan bagi warga binaan pemasyarakatan. Pelayanan kesehatan komprehensif pelayanan kesehatan promotif, preventif, kuratif, rehabilitatif, pelayanan kebidanan, dan Pelayanan Kesehatan Darurat Medis, termasuk pelayanan penunjang yang meliputi pemeriksaan laboratorium sederhana dan pelayanan kefarmasian sesuai dengan ketentuan peraturan perundang-undangan.Pada kegiatan pelayanan kesehatan di Rumah Tahanan Negara Kelas 1 Cipinang selalu melakukan tindakan-tindakan 
pencegahan, penyembuhan, pemulihan, dan peningkatan terhadap kesehatan. Adapun kendala yang di alami petugas medis dalam melakukan pelayanan kesehatan yaitu karena prasarana yang kurang menunjang dan jumlah personil tenaga medis yang kurang. Upaya yang di lakukan tenaga medis dalam mengoptimalkan kinerjanya dengan selalu berupaya melengkapi sarana dan prasarana. Berdasarkan hasil analisis pula, penulis memberikan saran bahwa solusi untuk mengatasi kekeuragan tenaga medis yaitu dengan cara menjalankan klinik online (Telemedicine).

Kata kunci: Pelayanan; Telemedicine; Kesehatan

\section{Pendahuluan}

Pelayanan kesehatan di dalam Lembaga Pemasyarakatan/Rumah Tahanan Negara selama ini masih sangat kurang memadai. Seringkali narapidana dan tahanan dihadapkan dengan sulitnya untuk mendapatkan pelayanan kesehatan bagi mereka yang menderita gangguan kesehatan. Praktik penyelenggaraan pelayanan kesehatan di Lapas/Rutan di seluruh Indonesia saat ini jauh dari optimal data yang diperoleh dari Sistim Data Base Pemasyarakatan tahun 2017 menunjukan bahwa dari 494 Unit pelayanan teknis Pemasyarakatan seluruh Indonesia (Lapas, Rutan dan Cabang Rutan) terdapat 221.763 orang penghuni dengan kapasitas 121.961 orang, namun diseluruh Indonesia belum seluruhnya unit pelayanan teknis yang dapat di kategorikan memenuhi persyaratan pelayanan kesehatan yang optimal (R. Benny Riyanto, Zulkifli, Ahmad Sanusi, Hakki Fajriando, Haryono, Nizar Apriansyah, Trisapto W. A. Nugroho, Imam Lukito, Bintang M. Tambunan, Susena, 2018).

Dari data yang didapat Direktorat Jenderal Pemasyarakatan dan Sistem Data Base Pemasyarakatan menunjukan bahwa kondisi kesehatan penghuni lapas/rutan sangat memprihatinkan. Pada tahun 2013 sampai 2015 narapidana dan tahanan yang mengalami gangguan kesehatan di seluruh Indonesia menunjukan jumlah yang tidak sedikit, pada tahun 2013 berjumlah 7.740 orang atau 4,9\%, tahun 2014 berjumlah 22.445 orang atau $13,9 \%$ dan tahun 2015 berjumlah 22.027 orang atau 12,7\% orang dari total narapidana dan tahanan di seluruh Indonesia

Dari kendala tersebut maka yang menjadi kekhawatiran jajaran Pemasyarakatan tidak terpenuhinya pelayanan kesehatan terhadap narapidana/tahan yang tentunya menjadi pelanggaran yang melanggar amanah Undang-Undang Pemasyarakatan.

Selain itu dikhawatirkan akan menjadi potensi terjadinya gangguan keamanan dan ketertiban sehingga yang lebih di khawatirkan akan menjadi permasalahan penularan penyakit hingga kematian yang di akibatkan ketidak hadirnya peran tenaga medis dalam menanggulangi permalasalahan kesehatan.

Berdasarkan data dari Direktorat Jenderal Pemasyarakatan menunjukan angka kematian narapidana dan tahanan yang disebabkan penyakit pada tahun 2014 mencapai 399 orang atau 0,24\% dan di tahun 2015 mencapai 425 atau 0,24\% dari seluruh jumlah narapidana dan tahanan diseluruh Indonesia. Sangat pentingnya peran tenaga medis di lembaga pemasyarakatan, sehingga dapat dikatakan memegang kunci keberhasilan didalam pencapaian tujuan sistem pemasyarakatan. 
Dengan kondisi serba keterbatasan seperti inilah yang menjadi daya pacu untuk selalu mengasah kemampuan dan berfikir secara luas dengan memanfaatkan teknologi yang ada tanpa memerlukan biaya yang besar, sehingga paradigma tentang keterbatasan anggaran menjadi terbantahkan, sesuai dengan program kerja Menteri Hukum dan HAM dengan selogan gerakan kerja kami PASTI yang dalam hufu I berarti Inovasi dan memanfaatkan e-goverment yang di lakukan oleh Kementerian Hukum dan Hak Asasi Manusia. Memanfaatkan teknologi informasi dan komunikasi dalam pelaksaanaan pelayanan kesehatan merupakan salah satu solusi dalam rangka mengatasi kekurangan sumber daya manusia (Hasibuan, 2010). Program media sosial yang dijalankan sepenuhnya merupakan mekanisme komunikasi terintegrasi yang memperkuat dampak dari setiap fungsi dalam organisasi, dengan memanfaatkan kekuatan jejaring manusia melalui jalur jejaring sosial.Program ini merupakan alternatif dari bentuk taktik komunikasi. Dalam istilah militer,media sosial adalah sebuah pelipat ganda kekuatan, sebuah elemen taktik yang membuat suatu kekuatan menjadi jauh lebih efektif dibandingkan tanpa element tersebut (Natalia, 2015).

Rumusan masalah dari penelitian ini dari latar belakang di uraikan bahwa tenaga medis yang bertugas di lapas/rutan di seluruh wilayah indonesia belum sepenuhnya terpenuhi. Data dari Direktorat Jenderal Pemasyarakatan pada tahun 2016 menunjukan bahwa jumlah tenaga kesehatan yang meliputi dokter umum,dokter gigi, perawat, psikolog/psikiater,apoteker,bidan dan ahli gizi yang tersedia di Lapas dan Rutan seluruh Indonesia Pada tahun 2016 hanya berjumlah 1.062 orang, dengan 341 orang paruh waktu dan 721 purna waktu. Jumlah tersebut sangat jelas tidak seimbang dengan penghuni lapas dan rutan di seluruh indonesia yang berjumlah 197.159 orang seluruh Unit. Pelayanan Teknis Pemasyarakatan (Lapas, Rutan dan Cabang Rutan). Maka diketahui bahwa perbandingan (rasio) tenaga dokter dengan jumlah narapidana dan tahanan adalah 1:185 artinya 1 orang petugas medis atau paramedis harus melayani 185 orang narapidana/tahanan.

Namun dari seluruh unit pelayanan teknis pemasyarakatan diseluruh Indonesia belum sepenuhnya terpenuhi khususnya dalam bentuk tenaga medis,sehingga di khawatirkan jika hal ini terus menerus di biarkan akan menjadi masalah besar bagi Pemasyarakatan, sehubungan dengan selogan gerakan kerja kami PASTI yang dalam huruf I berarti Inovasi dan memanfaatkan e-goverment yang di lakukan oleh Kementerian Hukum dan Hak Asasi Manusia, maka seyogyanya sebagai insan pemasyarakatan memiliki tanggung jawab terhadap organisasi.

Perlindungan dan pengakuan terhadap hak atas pelayanan kesehatan bagi narapidana dan tahanan juga diatur dalam berbagai instrumen internasional. Instrumen internasional yang mengatur tentang hak atas pelayanan kesehatan bagi narapidana dan tahana tersebut antara lain adalah Standard Minimum Rules for The Threatmen of Prisoners (Conferences, 1955) Artikel 22 (1) menjelaskan bahwa pada setiap lembaga akan ada tersedia layanan dari setidaknya satu petugas medis yang berkualitas yang harus memiliki pengetahuan psikiatri. Pelayanan medis harus diatur di dekat hubungan administrasi kesehatan umum masyarakat atau bangsa, mereka harus mencakup psikiatri 
untuk diagnosis dan, dalam kasus yang tepat, pengobatan negara mental kelainan, SMR artikel 24 menjelaskan bahwa Petugas medis harus melihat dan memeriksa setiap tahanan sesegera mungkin setelah pengakuannya dan setelah itu diperlukan, dengan maksud terutama untuk penemuan penyakit fisik atau mental dan pengambilan semua tindakan yang diperlukan; pemisahan tahanan yang dicurigai infeksi atau kondisi menular; yang mencatat cacat fisik atau mental yang mungkin menghambat rehabilitasi, dan penentuan kapasitas fisik setiap narapidana untuk bekerja.SMR artikel 25 (1) Petugas medis harus memiliki perawatan kesehatan fisik dan mental para tahanan dan sehari-hari harus melihat semua tahanan yang sakit, semua yang mengeluh sakit, dan setiap tahanan kepada siapa perhatiannya secara khusus diarahkan.

Keseluruhan produk hukum tersebut secara ideal merupakan landasan bagi negara untuk memenuhi hak-hak dasar para narapidana dan tahanan demi terwujudnya keadilan, sekaligus dalam rangka penghormatan terhadap harkat dan martabat manusia yang juga merupakan salah satu sistem pembinaan pemasyarakatan. Dalam menjalani pidananya hak dan kewajibannya telah diatur dalam Sistem Pemasyarakatan, yaitu suatu sistim pemidanaan yang baru yang menggantikan Sistim Kepenjaraan. Secara yuridis formal kegiatan pemasyarakatan telah mempunyai undang-undang sendiri, sesudah disahkannya Undang-Undang Republik Indonesia Nomor 12 Tahun 1995 tentang Pemasyarakatan (Republik Indonesia, 1995) Yang diundangkan pada tanggal 30 Desember 1995 Melalui Lembaran negara Republik Indonesia Nomor 13641.

Undang-Undang Nomor 12 Tahun 1995 tentang Pemasyarakatan menjelaskan bahwa suatu perlindungan bagi Warga Binaan Pemasyarakatan (WBP) yang harus dipenuhi oleh negara adalah hak untuk memperoleh pelayanan kesehatan yang layak. Ketentuan ini diakui eksistensinya dalam Pasal 14 Ayat (1) huruf d Undang Undang Nomor 12 Tahun 1995 tentang Pemasyarakatan mengenai hak-hak narapidana yang menyatakan bahwa Narapidana berhak mendapatkan pelayanan kesehatan dan makanan yang layak.

Peraturan Pemerintah Nomor 32 Tahun 1999 Tentang Syarat dan Tata Cara Pelaksanaan Hak Warga Binaan Pemasyarakatan (Sekretariat Republik Indonesia, 1999) Pasal 14 sampai pasal 18 juga mengatur mengenai pelayanan kesehatan bagi Warga Binaan Pemasyarakatan yang diantaranya adalah Pasal 14 (1) menerangkan bahwa setiap Narapidana dan Anak Didik Pemasyarakatan berhak memperoleh pelayanan kesehatan yang layak.

Dalam Penegakan Hukum, status kesehatan tahanan merupakan unsur penting terwujudnya proses peradilan yang cepat, lancar dan murah. Namun demikian, terlihat adanya gejala-gejala kelemahan di bidang pelayanan kesehatan ini. Contohnya adalah perihal surat keterangan sakit dan surat keterangan perlu perawatan dan sebgainya yang secara jelas digunakan untuk menghindari atau mengganggu proses penegakan hukum. Sehubungan denga itu upaya pelayanan kesehatan bagi narapidana dan tahanan di Lapas dan juga Rutan harus dioptimalkan.

Namun realitas sampai saat ini masih terdengar keluhan dari WBP karena pelayanan kesehatan yang belum berjalan sesuai dengan apa yang diharapkan. Hak atas 
kesehatan sebagai hak fundamental ternyata sering kali belum sepenuhnya terprioritaskan,seperti ketika narapidana/tahanan mengalami gangguan kesehatan. Namun petugas medis yang ada di poliklinik Lapas/Rutan/Cabang Rutan tidak dapat melakukan pelayanan karena kekurangan tenaga dokter umum,dokter gigi, perawat, psikolog, apoteker dan ahli gizi, serta sarana dan prasarana yang menunjang..

Seperti yang tertuang Dalam Peraturan Pemerintah Nomor 32 Tahun 1999 Tentang Syarat dan Tata Cara Hak Warga Binaan Pemasyarakatan Pasal 14 ayat 2 menyatakan bahwa: Pada setiap lembaga pemasyarakatan disediakan poliklinik beserta fasilitasnya dan disediakan sekurang-kurangnya seorang dokter dan seorang tenaga kesehatan lainnya. Namun apapun masalahnya yang ada di organisasi Pemasyarakatan ini harus segera di akhiri dan sebagai insan pemasyarakatn harus dapat berinovasi dalam mencari jalan keluarnya.

Dengan adanya gerakan kerja ini,perlu dilakukan perubahan stratejik dalam konteks pelayanan kesehatan ditengah hiruk pikunnya permasalahan fasilitatif dan sumber daya manusia yang terjadi di organisasi Pemasyarakatan, untuk itu perlu adanya pemikiran baru dan berinovasi dengan memanfaatkan teknologi informasi dan komunikasi yang dewasa ini sangat berkembang di Indonesia khususnya di Pemasyarakatan, dengan adanya Sistem Data Base Pemasyarakatan dapat termonitor segala bentuk laporan kegiatan, informasai mengenai pelayanan yang dilaksanakan Unit Pelayanan Teknis Pemasyarakatan.

Pelayanan kesehatan yang kurang maksimal di karnakan keterbatasan dukungan sumber daya manusia, yang idelanya adalah terpenuhinya dukungan fasilitatif dan sumber daya manusia, untuk itu hal ini dapat di atasi dengan cara melakukan inovasi pelayanan yaitu dengan memanfaatkan fitur dari video call untuk Lapas,Rutan dan Cabang Rutan yang belum memiliki tenaga dokter.Kondisi seperti terjadi dikarnakan faktor geografis Lapas, Rutan dan Cabang Rutan yang jauh dari jangkauan,terhambat oleh akses yang sulit di jangkau, dan yang terpenting adalah negara belum sepenuhnya hadir dalam mendukung pelaksanaan pelayanan kesehatan bagi narapidan dan tahanan di Lapas,Rutan dan Cabang Rutan di seluruh indonesia khusunya di daerah terpencil. Tujuan dari pelaksanaan penelitian ini yaitu: 1) Menganalisis pelaksanaan pelayanan kesehatan bagi narapidana dan tahanan di Rumah Tahanan Negara kelas I Cipinang. 2) Menganalisis kendala dalam pelayanan kesehatan di Rumah Tahanan Negara Kelas 1 Cipinang

Dalam penelitia ini menunjukan bahawa Penggunaan teknologi video untuk examinasi dan konsultasi penanganan penyakit pada bagian-bagian tubuh yang berukuran mikroskopis untuk telepathology telah dibuktikan berhasil dilakukan, meskipun dengan sejumlah beberapa kendala teknis yang belum terselesaikan sampai saat itu. Ada dua paradigma utama di dalam telepathology,yaitu :

1. Screening secara dinamis dari jarak jauh dengan robot yang dipperlengkapi dengan video mikroskopis: lebih menarik bagi kebanyakan ahli patologi, namun memerlukan kecepatan link telekomunikasi yang sangat tinggi dan mahal yang mungkin tidak tersedia di lokasi-lokasi tertentu. 
2. Diagnosa jarak jauh gambar still video hasil rekaman yang telah dipilih : mengalami penurunan yang signifikan dari data yang dibutuhkan untuk diagnosis. Sebagai solusinya terdapat sistem hibrid yang menggabungkan keterbatasan kemampuan robot yaitu dengan tetap menggunakan still image dengan resolusi tinggi.Relevansi dengan penelitian ini adalah sebagai alat bantu pelayanaan kesehatan ,pelayanan berbasis teknologi informasi dan komunikasi dapat digunakan namun hanya untuk penyakit tertentu, artinya belum dapat digunakan untuk penanganan medis yang berat seperti oprasi,pertolongan pertama pada kecelakaan.

Penelitian ini dilakukan untuk mengetahui bagaimana model pelayanan kesehatan berbasis Teknologi Informasi yang dilaksanakan dalam rangka mengatasi kekurangan tenaga medis di Rumah Tahanan Negara kelas I Cipinang. Proses penelitian ini dilakukan dengan meninjau dan melihat secara langsung permasalahan yang terjadi dilokasi penelitian yang disebabkan kurangnya tenaga medis. Maka dari penelitian ini akan diperoleh solusi dalam mensiasati keterbatasan sumber daya manusia.

\section{Metode Penelitian}

Metode yang digunakan dalam penelitian ini adalah metode kualitatif. Metode penelitian kualitatif sangat berhubungan langsung dengan sasaran hingga diperoleh pemahaman yang lebih mendalam. Jenis penelitian yang digunakan dalam penelitian adalah deskriptif, penelitian deskriptif adalah suatu penelitian Penelitian kualitatif deskriptif menafsirkan dan menuturkan data yang bersangkutan dengan situasi yang sedang terjadi, sikap serta pandangan yang terjadi di dalam masyarakat, hubungan antarvariabel, perbedaan antar fakta, pengaruh terhadap suatu kondisi, dan lain-lain. Penelitian ini dilakukan di Lembaga Pemasyarakatan Kelas I Cipinang, Jakarta Timur. Teknik pengumpulan data yang digunakan, misalnya observasi , wawancara mendalam, dokumentasi dan lain-lain. Selain itu perlu dikemukakan cara-cara untuk memastikan keabsahan data dengan triangulasi dan waktu yang diperlukan dalam pengumpulan data. Untuk melengkapi dan menyempurnakan penelitian ini agar mendapatkan hasil yang selengkap-lengkapnya maka penulis menggunakan teknik wawancara dengan tenaga medis dan paramedis seperti dokter, perawat, apoteker, psikolog tahanan yang mengalmi gangguan kesehatan ringan maupun tahan yang konsisi kesehatannya dinyatakan sehat dan petugas yang ada di Rumah Tahanan Negara Kelas I Cipinang. Selain teknik wawancara teknik lain yang digunakan adalah teknik observasi, teknik observasi yaitu dengan pengamatan secara langsung dalam proses pelayanan kesehatan terhadap tahanan ketika dokter atau tenaga medis lainnya tidak berada ditempat pada Rumah Tahanan Negara Kelas I Cipinang, selain kedua teknik diatas teknik lain yang dapat digunakan penulis yaitu dengan teknik kepustakaan dimana pengumpulan data ini dilakukan dengan mempelajari buku-buku, dokumen, literatur, peraturan-peraturan yang berkaitan dengan pembahasan guna mendapatkan data yang diperlukan dalam penelitian. Dalam penelitian ini peneliti menentukan beberapa dengan informan yaitu; 1) Kepala Rumah Tahanan Negara Kelas 1 Cipinang; 2) Pejabat struktural/ fungsional; 3) Tenaga Medis; 4) Tahanana dan Narapidana. 
Teknik pengumpulan data yang digunakan untuk melengkapi dalam memperoleh data primer dan sekunder, observasi dan interview digunakan untuk menjaring data primer yang berkaitan dengan pelaksanaan pelayanan kesehatan di Rumah Tahanan Negara Kelas 1 Cipinang, sementara studi dokumentasi digunakan untuk menjaring data sekunder yang dapat diangkat dari berbagai dokumentasi. Berikut dijelaskan keabsahan temuan-temuan penelitian :

1. Credibility (derajat kepercayaan atau validitas internal)

Tujuannya untuk menggambarkan kecocokan konsep peneliti dengan konsep yang ada pada responden atau narsumber.

2. Transferabilitas (derajat keteralihan)

Dalam penelitian ini, transferabilitas digunakan untuk menjamin bahwa hasil penelitian yang diperoleh dapat diterapkan dalam situasi tertentu.

\section{Hasil dan Pembahasan}

Berdasarakan Undang- Undang Nomor 11 tahun 2008 tentang Informasi dan Transaksi Elektronik pasal 1 (3) (Keuangan, 2008), menyatakan bahwa Tekonologi Informasi adalah suatu teknik untuk mengumpulkan, menyiapkan, menyimpan, memproses, mengumumkan, menganalisis, dan/atau menyebarkan informasi.

Teknologi Informasi (TI) atau dalam bahasa Inggris dikenal dengan istilah Information technology (IT), (Hofman, 2010) istilah umum untuk teknologi apa pun yang membantu manusia dalam membuat, mengubah, menyimpan, mengkomunikasikan dan atau menyebarkan informasi. TI menyatukan komputasi dan komunikasi berkecepatan tinggi untuk data, suara, dan video. Contoh dari Teknologi Informasi bukan hanya berupa komputer pribadi, tetapi juga telepon, TV, peralatan rumah tangga elektronik, dan peranti genggam modern (misalnya ponsel/gadget).

Dalam konteks bisnis,yang dikutip oleh (Hofman, 2010) Information Technology Association of America menjelaskan Pengolahan, penyimpanan dan penyebaran vokal, informasi bergambar, teks dan numerik oleh mikroelektronika berbasis kombinasi komputasi dan Telekomunikasi. Istilah dalam pengertian modern pertama kali muncul dalam sebuah artikel 1958 yang diterbitkan dalam Harvard Business Review, (Leavitt dan Whisler,2013:234) berkomentar bahwa "Teknologi baru belum memiliki nama tunggal yang didirikan.Kita akan menyebutnya teknologi informasi (TI).

Teknologi Informasi adalah studi atau peralatan elektronika, terutama komputer, untuk menyimpan,menganalisa,dan mendistribusikan informasi apa saja, termasuk katakata, bilangan, dan gambar,dan juga Teknologi Informasi adalah seperangkat alat yang membantu anda bekerja dengan informasi dan melaksanakan tugas-tugas yang berhubungan dengan pemrosesan informasi. (Hofman, 2010). Berdasarkan kamus Oxford 1995 Teknologi Informasi (TI) dilihat dari kata penyusunnya adalah teknologi dan informasi. Kata teknologi bermakna pengembangan dan penerapan berbagai peralatan atau sistem untuk menyelesaikan persoalan-persoalan yang dihadapi oleh manusia dalam kehidupan sehari-hari, kata teknologi berdekatan artinya dengan istilah tata cara. 
Defenisi mengenai teknologi informasi Menurut McKeown yang dikutip oleh (Natalia, 2015) teknologi informasi merujuk pada seluruh bentuk teknologi yang digunakan untuk menciptakan, menyimpan, mengubah dan menggunakan informasi dalam segala bentuknya. Pendapat yang sama juga dikemukakan oleh Williams dan saywer yang dikutip oleh (Natalia, 2015) bahwa teknologi informasi merupakan sebuah bentuk umum yang menggambarkan setiap teknologi yang membantu menghasilkan, memanipulasi, menyimpan, mengkomunikasikan dan atau menyampaikan informasi.

Teknologi informasi dewasa ini menjadi hal yang sangat penting karena sudah banyak organisasi yang menerapkan teknologi informasi untuk mendukung kegiatan organisasi. Penerapan teknologi informasi pada tiap perusahaan atau organisasi tentunya memiliki tujuan yang berbeda karena penerapan TI pada suatu organisasi adalah untuk mendukung kepentingan usahanya. Adapun yang menjadi tujuan dari adanya teknologi informasi menurut (Natalia, 2015) untuk memecahkan masalah, membuka kreativitas, dan meningkatkan efektivitas dan efesiensi dalam melakukan pekerjaan.

Fungsi Teknologi Informasi menurut (Natalia, 2015) ada lima fungsi,yaitu :

1. Mengolah (Processing)

Mengkompilasikan catatan rinci dari aktivitas, misalnya menerima input dari keyboard, scanner, mic dan sebagainya. Mengolah/memproses data masukan yang diterima untuk menjadi informasi. pengolahan/pemrosesan data dapat berupa konversi (pengubahan data kebentuk lain), analisis (analisis kondisi), perhitungan (kalkulasi), sintesis (penggabungan) segala bentuk data dan informasi.

2. Menghasilkan

Menghasilkan atau mengorganisasikan informasi ke dalam bentuk yang berguna. Misalnya : laporan, tabel, grafik dan sebagainya

3. Transmisi

Mengirimkan data dan informasi dari suatu lokasi ke lokasi lain melalui jaringan computer. Misalnya mengirimkan data penjualan dari user A ke user lainnya dan sebagainya.

Berdasarkan pada lampiran Keputusan Direktur Jenderal Pemasyarakatan Nomor: PAS-14.OT.02.02 Tahun 2014 tentang Standar Pelayanan Pemasyarakatan (PAS, 2014) berikut ini adalah jenis layanan publik di UPT Pemasyarakatan khususnya di Lapas/Rutan yang telah ditetapkan dalam peraturan bidang kesehatan narapidana atau tahanan.

1. Layanan kesehatan

Pelayanan kesehatan dilaksanankan menurut Undang-Undang Nomor 12 Tahun 1995 tentang Pemsyarakatan (Presiden Republik Indonesia, 1995) dan Undang-Undang Nomor 36 Tahun 2009 tentang Kesehatan (Kemenkes, 2009). Sebagai bagian dari pelayanan kesehatan yang bersifat mandat di masing-masing Lapas/Rutan,setiap narapidana berhak mendapatkan layanan kesehatan yang layak.

Layanan ini diberikan kepada narapidana/tahanan berupa tindakan medis terkait dengan kondisi kesehatannya selama di Lapas/Rutan.Setiap Lapas/Rutan setidaknya menyediakan poliklinik beserta fasilitasnya. Layanan kesehatan ini diberikan bagi 
narapidana dalam bentuk pencegahan maupun pengobatan. Pencegahan dilakukan guna meminimalisir tersebarnya penyakit didalam Lapas/Rutan.Sedangkan pengobatan merupakan upaya untuk memberikan kesehatan bagi narapidana yang sedang menderita sakit agar program pembinaan dapat berjalan dengan optimal.

2. Layanan Rujukan Lanjutan di Luar Lapas/Rutan

Layanan rujukan lanjutan di luar Lapas/Rutan kepada narapidana bersifat permintaan ketika Lapas/Rutan tidak memiliki SDM atau fasilitas kesehatan yang tidak memadai. Maka Kepala Lapas/Rutan mengusulkan ke kanwil yang kemudian diteruskan ke Direktorat Jenderal Pemasyarakatan, dengan melengkapi persyaratan sebagai berikut:

a. Surat permohonan dari yang bersangkutan dengan dilengkapi surat pernyataan mampu membiayai dan tidak akan melarikan diri.

b. Surat rekomendasi dokter di Lapas/Rutan.

c. Rekam medis yang bersangkutan dari Lapas/Rutan.

d. Surat pengantar dari kantor wilayah.

3. Layanan Permintaan Rekomendasi Medis

Narapidana di Lapas/Rutan dapat meminta rekomendasi medis apabila didalam Lapas/Rutan belum ada fasilitas perawatan yang diperlukan. Dalam hal meminta rekomendasi medis dibutuhkan surat permohonan Kepala lapas ke kanwil dan diteruskan ke Dirjen Pemasyarakatan dengan melengkapi persyaratan sebagai berikut:

a. Surat permohonan dari yang bersangkutan dengan dilengkapi surat pernyataan mampu membiayai dan tidak akan melarikan diri.

b. Surat rekomendasi dokter di Lapas/Rutan.

c. Rekam medis yang bersangkutan dari Lapas/Rutan.

d. Surat pengantar dari kepala Lapas/Rutan.

e. Surat pengantar dari kantor wilayah.

Berdasarkan Peraturan Menteri Kesehatan Nomor 71 Tahun 2017 tentang pelayana kesehatan nasional Pasal 3 ayat 1 menyatakan bahwa (Kementerian Kesehatan, 2017):

Pelayanan kesehatan komprehensif pelayanan kesehatan promotif, preventif, kuratif, rehabilitatif, pelayanan kebidanan, dan Pelayanan Kesehatan Darurat Medis, termasuk pelayanan penunjang yang meliputi pemeriksaan laboratorium sederhana dan pelayanan kefarmasian sesuai dengan ketentuan peraturan perundang-undangan.Pada kegiatan pelayanan kesehatan di Rumah Tahanan Negara Kelas 1 Cipinang selalu melakukan tindakan-tindakan pencegahan, penyembuhan, pemulihan, dan peningkatan terhadap kesehatan.Kegiatan-kegiatan ini dapat dijelaskan sebagai berikut :

1. Promotif / Upaya peningkatan kesehatan

a. Kebersihan perorangan. Setiap tahanan menjaga kebersihan diri masingmasing dengan cara :

1) Mandi 2 kali sehari 
2) Hygiene mulut

3) Pakaian selalu bersih

4) Menjaga kebersihan blok hunian

b. Penyuluhan kesehatan dimana petugas memberikan penyuluhan secara berkala mengenai lingkungan/perorangan, manfaat berolahraga, $\mathrm{P} 3 \mathrm{~K}$, pencegahan penyakit, dan penularan penyakit.

2. Preventif / Upaya pencegahan

a. Isolasi

Apabila seorang tahanan terjangkit penyakit menular maka yang bersangkutan harus diisolasikan atau diasingkan dari tahanan lainnya. Petugas kesehatan harus segera melaporkan ke Dinas Kesehatan setempat.

b. Pengendalian hewan pembawa penyakit

Untuk mencegah berjangkitnya penyakit yang ditularkan serangga / tikus maka perlu dilakukan pemberantasan terhadap hewan-hewan tersebut dengan cara penyemprotan terhadap serangga dan pembasmian terhadap tikus.

c. Kebersihan lingkungan

Tahanan diwajibkan menjaga kebersihan kamar mandi, WC, tempat tidur, tikar, dan peralatan makan / minum ( piring dan gelas ), tenaga sanitarian dari Dinas Kesehatan satu kali sebulan melakukan pemeriksaan kesehatan lingkungan serta memberikan saran-saran kepada Kepala Rutan.

d. Pemeriksaan berkala

Petugas kesehatan melakukan pemeriksaan fisik tahanan secara berkala / periodik 1 bulan sekali.

3. Kuratif / Upaya Penyembuhan

a. Pengobatan dasar meliputi :

1) Pemeriksaan dan pengobatan oleh dokter umum atau tenaga medis.

2) Pemeriksaan obat sesuai dengan indikasi obat

3) Pelayanan rujukan sesuai dengan indikasi medis

b. P3K

Untuk mengatasi terjadi kecelakaan dan keadaan darurat seperti luka, patah tulang, pingsan perlu diberikan penanganan yang tepat, untuk itu diterbitkan buku pedoman $\mathrm{P} 3 \mathrm{~K}$ bagi petugas .

c. Pengobatan Spesialistik

Untuk kasus-kasus yang tidak bisa ditangani oleh petugas kesehatan Rutan perlu dirujuk ke sarana kesehatan yang lebih baik dan lengkap, seprti Rumah Sakit Pengayoman dan Rumah Sakit Umum Daerah.Untuk itu perlu surat keterangan rujukan yang dibuat dokter Rutan yang ditunjuk.

\section{A. Kendala dalam pelaksanaa pelayanan kesehatan}

Adapun hambatan-hambatan yang dihadapi di Rumah Tahanan Kelas I Cipinang adalah sebagai berikut :

a. Peralatan medis dan obat-obatan 
Dalam pelaksanaan perawatan tahanan di Rumah Tahanan sarana adalah salah satu faktor pendukung pelaksanaannya.Namun penyediaan peralatan medis dan obat obatan masih belum dapat memenuhi kebutuhan.Berdasarkan keterangan Kepala Rutan mengatakan bahwa" :

"..kondisi peralatan medis kita memang kurang memadai, bayak peralatan yang rusak seperti tensimeter,alat bantu pernafasan, tabung oksigen, stetoskop, termometer, kasur, tempat tidur, kita pun kesulitan dalam pemenuhannya karna keterbatasan anggaran juga,namun sedang kami upayaka untuk segera di penuhi kebutuhannya. memang idealnya alat-alat ini harus lengkap agar pelayanan kesehatan tidak tergambat."

(Wawancara dengan Asep Sutandar, A.Md.IP, S.Sos.,M.Si, selaku Kepala Rumah Tahanan NegaraKelas 1 Cipinang,25 juni 2017)

Dari hasil wawancara tersebut menunjukan bahwa peralatan medis yang kurang menjadi kendala dalam pelayanan kesehatan, untuk itu diperlukan adanya pemenuhan kebutuhan peralatan medis dan dengan kondisi yang ada, pihak Ruta harus berusaha untuk tetap malakukan fungsi pelayanan kepada narapidana dan tahanan.Seperti yang dikatakan oleh koordinator dokter poliklinik Rutan bahwa:

“..peralatan kita memang kurang ,maka dari itu sedang diusulkan untuk pemenuhannya dengan data sebagai berikut : (Berdasarkan wawancara dengan dr.Julius Soemarli, koordinator dokter Rutan Cipinang,28 juni 2017)

Tabel 1

Usulan Perangkat Ruang Poliklinik

\begin{tabular}{lc}
\hline Jenis Peralatan & Jumlah \\
\hline Lemari Obat & 8 \\
\hline Tempat tidur & 8 \\
\hline Kasur & 8 \\
\hline Stetoskop & 6 \\
\hline Termometer & 6 \\
\hline Tensimeter & 6 \\
\hline Tabung oksigen dan alat bantu nafas & 20 \\
\hline
\end{tabular}

Pengusulan penambahan perangkat ruang poliklinik sebagai salah satu upaya agar pelayana kesehatan yang dilakukan oleh tenaga medis di Rumah Tahanan Negara Kelas 1 Cipinang dapat berjalan dengan optimal

b. Sumber Daya Manusia

Seorang petugas pemasyarakatan sebagai suatu sumber daya manusia yang menentukan arah dan tujuan, berhasil atau tidaknya program perawatan tahanan dalam perlakuan dan perlindungan terhadap haknya sesuai Hak Asasi Manusia guna proses penegakan hukum di Indonesia.

Oleh sebab itu seorang petugas pemasyarakatan harus benar-benar memiliki kemampuan dan keahlian dalam memperlakukan tahanan dan narapidana sesuai dengan peraturan yang berlaku karena keberadaan seorang 
petugas pemasyarakatan sangat penting sebagai motor penggerak dari pelaksanaan sistem pemasyarakatan itu sendiri.

Namun pada kenyataannya selama penulis melakukan penelitian, petugas pemasyarakatan yang berhubungan langsung dengan kegiatan perawatan tahanan di Rumah Tahanan Kelas I Cipinang sering terkendala dengan jumlah personel petugas medis/paramedis, dari jumlah peghuni 3801 orang dengan jumlah narapidana/tananan yang menderita gangguan kesehtan mencapai 255 orang tiap bulanya sehingga dalam penanganan kesehatan 6 orang dokter harus mampu menangani 42 orang tiap harinya, jumlah ini sangat tidak sebanding antar petugas dan tahanan dan narapidana kususnya dalam pelayanan kesehatan,seingga dalam pelakasanaan pelayanann kesehatan dan kegiatan administrasi seperti pengimputan data kesehatan narapidana dan tahanan ke dalam Sistim Data Base Pemasyarakatan dilakukan oleh tamping. Menurut keterangan narapidana yang menjadi tamping poliklinik Rutan Cipinang mengatakan bahwa:

“..iya pak,memang saya sering kali melakukan penanganan saat dokter gak ada di rutan, yaa biasanya karna cuti, sedang ada rapat dan lainnya pak, seperti saat ada pasien luka ringan saya bisa menjait luka itu karna sudah di ajarkan oleh dokter, tapi saya selalu telpon dokter dulu sebelum bertindak" (hasil wawancara dengan asep,tamping polikinik Rutan Cipinang, 28 juni 2017)

Begitu juga menurut pengakuan tahanan yang diberi tindakan oleh tamping poliklinik, ia mengatkan bahwa:

“..iya pak, saat itu kaki saya luka dan kepala saya pusing tapi pas saya berobat dokter gak ada karna sudah sore menjelang malam, jadinya saya dikasih tindakan sama tamping poliklinik" (hasil wawancara dengan iwan sagaji,tahanan Rutan Cipinang, 28 juni 2017)

Pernyataan ini menunjukan bahwa pelayanan kesehatan di Rutan cipinang sering dilakukan oleh tamping polikliki.Hal ini menjadi suatu permasalahan, dimana dalam pelaksanaan tugas dan fugsi pemasyarakatan tidak di perbolehkan tamping yang melakukan tidakan,khususnya pelayanan kesehatan yang menyangkut nyawa manusia.Menurut keterangan kepala seksi pelayanan tahanan Rutan cipinang, beliau mengatakan bahwa;

"...iya memang tidak dipungkiri lagi ketika tenaga dokter sedang tidak ada,jadi tamping yang melakukan tindakan, tetapi tamping tersebut sebelumnya diberikan ilmu tindaka medis yang bersifat darurat, dan juga biasanya tamping tersebut melakukan kordinasi dengan dokter via tepon" (Berdasarkan hasil wawancara dengan Rachmad Mintarja, A.Md.IP., S.Sos., M.Si,Kepalas seksi pelayanan tahanan Rutan kelas 1 Cipinang,21 juni 2017).

Hal ini menjadi kendala yang dihadapi petugas pemasyarakatan dalam melakukan pelayanan kesehatan karena keterbatasan sumber daya manusia, untuk itu perlu dilakukan inovasi dalma mengatasi keterbatasn sumberdaya manusia 
kususnya dalam pelaksanaan pelayanan kesehatan,seperti yang dituturka oleh dokter di Rutan Cipinang, beliau mengatakan bahwa : “...tamping yang melakukan tindakan medis itu sebelumya kami beri pelatihan, karna tamping itu sudah lama di poliklinik, yahh inilah kondisi lapanga dimana kita harus tetap melayani pasien dengan pasien mencapai 40 orang tiap hari dan jumlah dokter yang sedikit,menurut idealnya memang kita harus punya 10 dokter di rutan jadi bisa backup saat dokter yang lainnya tidak ada. Namun sesungguhnya hal ini dapat di atasi denga cara berinovasi, kita gak mungkin dong minta ke pusat untuk penambahan dokter, dan gak segampang itu juga prosesnya, kalau kita liat di jepang, ada namanya telemedicine, semacam layana kesehatan via online, dan kenapa enggak kita coba lakuka di rutan ini. (Berdasarkan wawancara dengan dr.Julius Soemarli,koordinator dokter Rutan Cipinang,28 juni 2017).

Dari data yang didapat dari hasil wawancara dan observasi lapangan menujukan bahwa adanya ketidak seimbangan antara jumlah petugas kesehatan dengan jumlah tahanan yang ada di Rutan Kelas 1 Cipinang, dan di tambah dengan peralatan medis yang kurang memadai sehingga dalam pelaksanaan pelayanan kesehataan kurang optimal.

Jika ditinjau dari teori service quality oleh Zeithaml, yang mengatakan bahwa pelayanan disebut berkualitas apabila pelayanan yang diterima relatif lebih memuaskan dilihat dari sudut pandang pelanggan,sudut pandang tersebut antara lain adalah (Zeithaml, 1990):

a. Tangible, yaitu bukti yang ditujukan oleh fasilitas fisik, peralatan yang digunakan, penampilan karyawan, material, dan sarana komunikasi.

b. Reliability,yaitu menyajikan jasa sesuai dengan janji dengan akurat dan memuaskan.

c. Responsiveness, yaitu kesediaan para karyawan untuk membantu pelanggan dan menyajikan pelayanan dengan segera.

d. Assurance, yaitu pengetahuan,keterampilan dan kemampuan serta sopan santun karyawan dalam memberikan pelayanan, aman dari bahaya, resiko, keraguan serta memiliki sifat dapat dipercaya.

e. Emphaty, yaitu kemudahan dalam berinteraksi, komunikasi yang baik, memberikan perhatian secara pribadi serta memahami kebutuhan dan keinginan pelanggan.

Maka dapat disimpulkan bahwa kulaitas pelayanan kesehatan di Rumah Tahanan Negara Kelas 1 Cipinang belum sepenuhnya optimal, dikarnakan masih adanya kekurangan seperti peralatan yang kurang memadai,obat-obatan yang kurang serta jumlah personil petugas medis yang tidak sebanding dengan jumlah narapidana dan tahanan. Untuk itu diperlukan adanya inovasi dalam mengatasi permasalah tersebut denga cara membuat layanan kesehatan berbasis teknologi informasi dan komunikasi (Telemedicine) guna pemenuhan hak narapidana dan tahanan agar dapat berjalan dengan optimal dan diharapkan dapat di implementasikan di Lapas/Rutan dan Rutan seluruh Indoenesia. 


\section{B. Perkembangan Aplikasi Telemedicine di dunia dan di Indonesia}

Saat ini telemedicine sudah menjadi bagai penting dalam sebuah pengobatan.Telemedicine telah mampu membawa tangan-tangan dokter keluar dari ruang praktek mereka dan menyentuh orang-orang sakit yang tinggal jauh di pelosok.Berikut contoh perkembangan aplikasi telemedicine di dunia dan Indonesia, (Natalia, 2015):

\section{Easy call me}

Masa sekarang banyak dokter sudah membangun kedekatan dengan pasien melalui telepon atau pesan singkat (SMS). Hal ini memungkinkan bagi dokter untuk menangani masalah khusus misalnya pasien hepatitis rawat jalan, atau pasien hipertensi rawat jalan, dan lain-lain.

Smart- home, smart patient

Teknologi ini merupakan teknologi untuk melakukan monitoring terhadap pasien, dimana pasien tetap berada dirumah selama menitoring. Teknologi ini dikembangkan oleh American Telemedicine Association (ATA), Home Telehealth dan Remote Monitoring.

\section{Robotic telemedicine}

Proyek ini dikembangkan oleh Offsite Care Inc. Robot ini memungkinkan dokter berkoordinasi dengan klinis atau rumah sakit setempat, sekaligus memeriksa pasien dari jarak jauh.

\section{Pakistan telemedicine project}

Pemerintah America Serikat bekerja sama dengan Inetnational Busines Machine (IBM) merupakan perusahaan yang memproduksi dan menjual perangkat keras dan perangkat lunak untuk membangun infrastruktur telemedicine di Holy Family Hospital Rawalpindi di Pakistan. Disini dibangun sebuah system telemedicine untuk mengkoneksikan dokter-dokter ahli di Amerika Serikat dengan rumah sakit tersebut melalui jaringan Wi-Max. Dokter berhubungan dengan pasien melalui webcam dan dengan perangkat-perangkat yang diopersaikan oleh perawat di RS tersebut.

\section{Sistem Pakar}

Sistem ini memodelkan pengetahuan pakar ke dalam system computer. Contoh penggunaan system pakar dalam dunia medis adalah dilakukan di http://easydiagnosis.com/. Dalam website tersebut kita bisa melakukan beragam penyakit yang mungkin kita derita dengan memilih modul-modul yang tersedia dalam website tersebut.

5. Aplikasi telemedicine dari Telkom (Indonesia)

Ditjen Bina Upaya Kesehatan berinisiatif mengimplementasikan e-health dalam bentuk telemedicine.Aplikasi telemedicine dari Telkom adalah cikal bakal terintegrasinya diagnosa medis secara nasional. Hal ini telah disampaikan dalam seminar telemedicine Tahun 2011. Saat ini pilot projet implementasi online diagnose medis adalah enam Rumah Sakit (RS) di Jakarta yaitu RS 
Pesahabatan,RS Dr. Cipto Mangunkusumo, RS Fatmawati, RS Darmais, RS Harapan Kita.

Berdasarkan keterangan dari dokter Rumah sakit Fatmawati mengatakan bahwa:

“..Telemedicine saat ini sudah banyak digunakan, terutama di negara maju seperti Amerika,bsebagai salah satu trobosan ketika pasien sulit bertemu dengan dokter dikala aktifitas padat,sebenarnya tidak ada masalah sih, hanya telemedichine ini sebagai cara pengobotan yang memang hanya untuk penyakit ringan.beberapa waktu yang lalu juga sempat rumah sakit ini menggunakan aplikasi ini tetapi masyarakat yang belum yakin dengan telemedicine" (Hasil Wawancara denga Dokter Nugroho Setia wan,Sp.And,dokter spesialis andrologi Rumah Sakit Fatmawati, 28 November 2017).

Pernyataan ini menunjukan bahwa pelayanan kesehatan di berbasis Teknologi Informasi dan Komunikasi ini merupakan suatu bentuk perkembangan teknologi dan sebagai alat bantu dalam pelaksanaan pelayanan kesehatan bagi manusia menurunkan angka kematian dan angka kesakitan serta meningkatkan keberhasilan pengobatan bagi manusia. Telemedicine adalah suatu pemanfaatan teknologi informasi bagi kesehatan melalui online yang mana menghubungkan dokter dan pasien dalam bentuk medical chatting, medical webcam untuk menginformasikan tentang kesehatan, gejala penyakit dan pengobatan serta perawatan (Simarmata et al., 2020) (Carpenter, 2015). Dengan adanya pelayanan kesehatan berbasis online seperti yang sudah banyak dijalankan di dunia dan di Indonesia, bukan hal yang tidak mungkin jika pelayanan kesehatan berbasis online dapat diterapkan di Rumah Tahanan Negara Kelas 1 Cipinang sebagai solusi mengatasi kekurangan tenaga medis,namum pelayanan kesehatan ini terbatas yaitu hanya penanganan penyakit ringan.

\section{Kesimpulan}

Pelayanan kesehatan di Rumah Tahanan Kelas I Cipinang dilakukan sesuai dengan peraturan yang berlaku, namun dalam pelaksanaannya masih belum optimal. Kekurangan peralatan medis dan obat-obatan serta tidak seimbangnya antara jumlah tenaga medis dan paramedis dengan tahanan menjadikan pelayanan kesehatan di Rumah Tahaanan Kelas 1 Cipinang belum optimal dan dalam pelaksanaan pelayanan kesehatan serta kegiatan administrasi sering dilakukan oleh tamping. Dan pada saat ini pelayanan kesehatan berbasis Teknologi Informasi Dan Komunikasi (TIK) di dunia dan di Indonesia sudah mulai banyak dijalankan sehingga bukan hal yang tidak mungkin jika pelayanan kesehatan berbasis Teknologi Informasi dan Komunikasi (TIK) dapat diterapkan di Rumah Tahanan Negara Kelas 1 Cipinang sebagai solusi mengatasi kekurangan tenaga medis,namum pelayanan kesehatan ini terbatas yaitu hanya penanganan penyakit ringan. 


\section{BIBLIOGRAFI}

Carpenter, Jennifer E. (2015). Managing Multimedia Medical Records: E- Health Information Manager's Role And Telepatology. Jakarta: Cipta Sarana.

Conferences, United Nations Specialised. (1955). Standard Minimum Rules for the Treatment of Prisoners. Retrieved November 4, 2020, from refworld website: https://www.refworld.org/docid/3ae6b36e8.html.

Hasibuan, Zainal. (2010). Kerangka Strategis E-Health Indonesia: Optimalisasi Layanan Kesehatan Prima. Yogyakarta: Forum Informatika Kesehatan Indonesia.

Hofman, B. (2010). Basic Informatic Technology: Introduction For Informatic technology. Bandung: Sarana Cipta.

Indonesia, Presiden Republik. (1995). Undang-Undang Nomor 12 Tahun 1995 tentang Pemsyarakatan. Jakarta: Presiden Republik Indonesia.

Indonesia, Republik. (1995). Undang-Undang No. 12 Tahun 1995 tentang Sistem Pemasyarakatan. Jakarta: Lembaran Negara RI.

Indonesia, Sekretariat Republik. (1999). Peraturan Pemerintah No. 32 Tahun 1999 Tentang Syarat dan Tata cara Pelaksanaan Hak Warga Binaan Pemasyarakatan. Jakarta: Sekretariat Republik Indonesia.

Kemenkes, R. I. (2009). Undang-Undang Nomor 36 Tahun 2009 tentang Kesehatan. Jakarta: Kementerian Kesehatan RI.

Kesehatan, Kementerian. (2017). Peraturan Menteri Kesehatan No 71 tahun 2017 Tentang Pelayanan Kesehatan Nasional. Jakarta: Kementerian Kesehatan Republik Indonesia.

Keuangan, Kementerian. (2008). Undang- Undang Nomor 11 tahun 2008 tentang Informasi dan Transaksi Elektronik. Jakarta: Presiden Republik Indonesia.

Natalia, Sutarman. (2015). Social Media ROI : Mengelola dan Mengukur Penggunaan Media Sosial pada Organisasi Anda. Jakarta: Alex Media Komputindo.

PAS, Ditjen. (2014). Keputusan Direktorat Jenderal Pemasyarakatan tentag Standar Pelayanan Pemasyarakatan. Jakarta: Direktorat Jenderal Pemasyarakatan.

R. Benny Riyanto, Zulkifli, Ahmad Sanusi, Hakki Fajriando, Haryono, Nizar Apriansyah, Trisapto W. A. Nugroho, Imam Lukito, Bintang M. Tambunan, Susena, Edy Sumarsono dan Emmy Taurina Adriani. (2018). Analisis Terhadap Pelaksanaan Layanan Kesehatan Bagi Tahanan, Narapidana Dan Anak Didik Pemasyarakatan. Jakarta: Balitbangkumham Press.

Simarmata, Janner, Chaerul, Muhammad, Mukti, Retno Cahya, Purba, Deddy 
Pelayanan Kesehatan Berbasis TI dalam Proses Pemenuhan Hak-Hak Tahanan dan Narapidana

Wahyudin, Tamrin, Andi Febriana, Jamaludin, Jamaludin, Suhelayanti, Suhelayanti, Watrianthos, Ronal, Sahabuddin, Andi Arfan, \& Meganingratna, Andi. (2020). Teknologi Informasi: Aplikasi dan Penerapannya. Medan: Yayasan Kita Menulis.

Zeithaml, P. (1990). Quality Service. Jakarta: Media Komputindo. 